Relations industrielles

Industrial Relations

\title{
Our Third Year
}

\section{The Editors}

Volume 3, numéro 1, septembre 1947

URI : https://id.erudit.org/iderudit/1023561ar

DOI : https://doi.org/10.7202/1023561ar

Aller au sommaire du numéro

Éditeur(s)

Département des relations industrielles de l’Université Laval

ISSN

0034-379X (imprimé)

1703-8138 (numérique)

Découvrir la revue

Citer ce document

The Editors (1947). Our Third Year. Relations industrielles / Industrial Relations, 3(1), 16-16. https://doi.org/10.7202/1023561ar

Tous droits réservés @ Département des relations industrielles de l’Université Laval, 1947
Ce document est protégé par la loi sur le droit d'auteur. L’utilisation des services d'Érudit (y compris la reproduction) est assujettie à sa politique d'utilisation que vous pouvez consulter en ligne.

https://apropos.erudit.org/fr/usagers/politique-dutilisation/ 


\section{OUR THIRD YEAR}

With the publication of the present issue the « Bulletin des Relations Industrielles 》 is entering its third year of existence. Despite the apprehensions of some of our friends, who doubted the possibility of its survival though they understood the necessity for such a specialized organ, the Bulletin continues to bring each month to labour and managenıent information and doctrine conducive to greater mutual understanding between these two fields and that will foster the establishment of sound labour relations within the precepts of peace, order, justice and charity.

In the midst of this turmoil, in which even the keenest minds are apt to be led astray, nobody is in a better position than we are to realize how difficult it is to distinguish the essential from the accessory, the permanent from the transitory. However, the prominent part to be played by our University which draws its inspiration from the teachings of the Church's social doctrine and which follows modern scientific methods, is to fearlessly affirm what it considers necessary in labour relations and to remain above factiousness.

In His message to the «Semaine sociale de Paris », Pope Pius XII said lately:

\& The present hour. requires that the faithful spares no effort in having the social doctrine of the Church yield its utmost in efficiency and realization... The Catholics shall maintain and improve their position only in as much as they have the courage to materialize their convictions throughout the entire fields of public and private life.

Such was the aim of the founders of this review and our intention is to follow the course they have set for us.

The faithfulness with which our readers renew their subscriptions, and the ever increasing number of new subscribers to the Bulletin constitute strong encouragement for us to keep to the same line of conduct. That is not all; hardly ever a month passes without certain articles published in the Bulletin being reproduced in some other newspapers and reviews of the management or labour fields or even in Canadian or foreign government organs. In this respect, we are particularly pleased to mention that, last year, the «Revue Française du Travail» and the «Monthly Labor Review» gave their readers of France and of the United States respectively a summary of an article which had first appeared in our review. Such unequivocal tributes coming from all sides urge us to carry on with the policy we adopted.

A few of our French-speaking subscribers have pointed out to us that we are loosing quite an amount of space in publishing a bilingual bulletin since, as they claim, most of our English-speaking readers understand French. As we have a considerable number of English-speaking readers and as we believe it essential to make known to them a Catholic French university's teachings in this field, we have, up to now, made it a point to publish most of our articles in both languages. However, we would be very grateful to our English speaking subscribers if they would be so kind as to set forth their opinion on the matter and thus let us know if we should maintain the bilingual publication of our Bulletin.

Our readers will be pleased to notice that the present issue comprises certain improvements. Indeed, in future, our publication shall include sixteen pages instead of eight. It is also to be noted that in spite of increased publication costs, the subscription fee will remain unchanged. By the way, certain friends of ours suggested that we should publish a page of advertisements in order to compensate the difference in cost and make ends meet; but we have decided not to have recourse to such a means so as to avoid giving the impression that we might not be free to express our ideas. Thus, it will be necessary for us to increase the number of our subscribers, and to do so, we rely entirely upon our faithful readers (to whom the Bulletin has proved its value) to promote subscriptions in their respective circles. We feel confident that they will not fail to grant us their undivided assistance, knowing as they do, that we are performing useful and even indispensable work in the field of labour relations. 